\begin{tabular}{|l|l|l|}
\hline \multicolumn{2}{|c|}{ PublisherInfo } \\
\hline \hline PublisherName & $:$ & BioMed Central \\
\hline \hline PublisherLocation & $:$ & London \\
\hline \hline PublisherImprintName & $:$ & BioMed Central \\
\hline \hline
\end{tabular}

\title{
Could selfish DNA create new proteins?
}

\begin{tabular}{|l|l|l||}
\hline \multicolumn{2}{|c|}{ ArticleInfo } \\
\hline \hline ArticleID & $:$ & 3799 \\
\hline \hline ArticleDOI & $:$ & $10.1186 /$ gb-spotlight-20001017-01 \\
\hline \hline ArticleCitationID & $:$ & spotlight-20001017-01 \\
\hline \hline ArticleSequenceNumber & $:$ & 236 \\
\hline \hline ArticleCategory & $:$ & Research news \\
\hline ArticleFirstPage & $:$ & 1 \\
\hline \hline ArticleLastPage & $:$ & 2 \\
\hline \hline & & RegistrationDate : 2000-10-17 \\
ArticleHistory & $:$ & OnlineDate $\quad$ 2000-10-17 \\
\hline \hline ArticleCopyright & $:$ & BioMed Central Ltd2000 \\
\hline \hline ArticleGrants & $:$ & \\
\hline \hline ArticleContext & $:$ & 130591111 \\
\hline \hline
\end{tabular}




\section{William Wells}

Email: wells@biotext.com

Selfish DNA has been defined as DNA "with no phenotypic expression whose only 'function' is survival within genomes." In the 13 October Science, [http://www.sciencemag.org/] Ogata et al. find what appears to be selfish DNA lodged in the middle of 19 genes of Rickettsia conorii [http://www.genomebiology.com/resolver.asp?PubMedID=9336669], an intracellular bacterium of ticks (Science 2000, 290:347-350). The repeats are palindromes that encode a mildly hydrophobic $\alpha$ helix surrounded by two extended or coil regions. This appears to be a non-functional module that has been inserted at the surface of a collection of unrelated proteins. Although the inserts probably do not provide a specific function, genetic drift from the original sequence could allow the evolution of new protein sequences, domains and functions.

\section{References}

1. Selfish genes, the phenotype paradigm and genome evolution.

2. Science, [http://www.sciencemag.org/]

3. Rickettsioses as paradigms of new or emerging infectious diseases. 